\title{
PENGELOLAAN MODAL KERJA SEBAGAI UPAYA MENINGKATKAN NILAI PROFITABILITAS DAN TINGKAT LIKUIDITAS KOPERASI
}

\author{
Rizki Aprilia Dwi Susanti \\ Universitas Tribhuwana Tunggadewi \\ E-mail: rizkiunitri2@gmail.com
}

\begin{abstract}
This study aims to determine the management of working capital because it is very important for cooperatives in carrying out its operations to improve the profitability of cooperatives and can also maintain the level of cooperative liquidity. This type of research is qualitative descriptive with a quantitative approach. The results of this study showed under the working capital of Indonesian officials of Universitas Brawijaya Malang derived from members and capital of their own. The profitability of cooperatives in three years was increased in this case Due to the rise of assets from the net profit after tax while the liquidity is fluctuating due to the reduced cooperative cash used to fulfill a short-term obligation that results in declining liabilities The short-term cooperative in three years was in 2016 until 2018.
\end{abstract}

Keywords: working capital; profitability; liquidity.

\begin{abstract}
ABSTRAK
Penelitian ini bertujuan untuk mengetahui pengelolaan modal kerja karena sangat penting bagi koperasi dalam menjalankan operasionalnya untuk meningkatkan profitabilitas koperasi dan juga dapat menjaga tingkat likuiditas koperasi. Jenis penelitian ini adalah kualitatif deskriptif dangan pendekatan kuantitatif. Hasil penelitian ini menunjukan bawah sumber modal kerja Koperasi Pegawai Republik Indonesia Universitas Brawijaya Malang berasal dari anggota dan modal sendiri. Pengelolaaan profitabilitas koperasi dalam tiga tahun terakhi mengalami kenaikan hal ini disebabkan oleh naiknya aktiva dari pada laba bersih setelah pajak sedangkan likuditas mengalami fluktuasi hal ini disebabkan oleh berkurangnya kas koperasi yang digunakan untuk memenuhi kewajiban jangka pendeknya yang mengakibatkan menurunya kewajiban jangka pendek koperasi dalam tiga tahun terakhi yaitupada tahun 2016 sampai dengan tahun 2018.
\end{abstract}

Kata Kunci: modal kerja; profitabilitas; likuiditas.

\section{PENDAHULUAN}

Koperasi merupakan salah satu sektor usaha penggerak perekonomian, dimana tujuan utama dari koperasi adalah untuk mensejahterakan para anggota-anggotanya sebagaimana asas yang dianut yaitu asas kekeluargaan menjadikan koperasi menjadi sngata relevan untuk menyokong perekonomian bangsa Indonesia, khusunya masyarakat kecil dan menengah. menurut Undang-Undang Indonesia No. 17 Tahun 2012 tentang koperasi dijelaskan bahawa koperasi merupakan badan usaha yang memiliki badan hukum didirikan oleh

Cara mengutip: Susanti, R.,A.,D. 2020. Pengelolaan Modal Kerja Sebagai Upaya Meningkatkan Nilai Profitabilitas dan Tingkat Likuiditas Koperasi. Referensi : Jurnal Ilmu Manajemen dan Akuntansi, 8(1), 79-89 
orang atau perseorangan dengan menjadikan kekayaan para anggotanya sebagai modal untuk menjalankan usaha, yang memenuhi kebutuhan bersama dibidang ekonomi, social dan budaya sesuai dengan nilai dan prinsip koperasi. Memiliki tujuan utama yaitu menjsejahterakan anggotanya , maka koperasi harus mampu mengelola modal kerjanya dengan efektif dan efisien. modal kerja merupakan suatu hal yang sangat pentig dalam sebuah usaha tidak terkecuali koperasi. Dengan modal kerja tersebut koperasi akan mampu memenuhi kebutruhan operasional koperasi. Enriques dalam Arifin (2001:13) juga menyatakan bahwa koperasi yaitu menolong sama lain (to help one another) atau saling bergandengan tangan (hand in hand).

Pada praktiknya ada beberapa masalah yang seringkali dihadapi oleh koperasi dalam menjalankan usahanaya. pertama, pertumbuhan jumlah anggota. anggota menjadi sangat penting bagi koperasi karena dari keberadaaan anggota inilah koperasi mampu memenuhi modalnya. semakin banyak anggota maka akan semakin banyak modal, begitupun sebaliknya jika anggota koperasi sedikit maka sedikit pula jumlah modal yang bisa dikelola. Kedua adalah unit usaha yang dijalankan oleh kperasi, unit usaha menajdi hal juga penting karena unit usaha bisa menjadi sumber laba bagi koperasi sehingga dapat juga meningkatkan profitabilitas. untuk menjalankan sebuah unit usaha, tentunya koperasi membutuhkan modal kerja, jika modal kerja terbatas maka pengembangan unit usaha juga akan terhambat. Ketiga adalah masalah manajemen modal kerja yang kurang baik. Modal kerja sudah sepatutnya dikelola oleh setiap manajemen koperasi, oleh karenanya kemampuan dalam mengelola modal kerja harus dimiliki oleh setiap manajemen koperasi. Pengelolaan yang kurang baik anakn menjadi masalah untuk pertumbuhan koperasi. tingkat efektfitas serta efisiensi pengelolaan modal kerja akan dilihat dari semakin tinggi rasio profitabilitas yang dimiliki koperasi dalam menghasilkan laba. Manajemen yang baik adalah manajemen modal kerja yang diperlukan dalam mempertimbangkan keputusan investasi pada aset lancar dan utang lancar (Fauziyyah \& Husaini, 2017). Modal kerja adalah keseluruhan aktiva lancar yang dimiliki perusahaan atau dapat pula dimaksudkan sebagai dana yang harus tersedia untuk membiayai kegiatan operasi perusahaan sehari-hari (Azlina. 2009).

$$
\text { Koperasi Pegawai Republik }
$$

Indonesia (KPRI) Universitas Brawijaya Malang, merupakan yang memiliki unit usaha dibidang pelayanan dan perdagangan, diantaranya adalah usaha perdaganagn umum, simpan pinjam dan beberapa usaha lainnya. KPRI UB Malang merupakan koperasi yang pengelolaannya telah modern dan telah dijalankan secara proposional dalam mewujudkan tujuan koperasi yaitu mensejahterkana anggota koperasi. Untuk mewujudkan tujuan tersebut, Koperasi perlu melakukan upaya pengelolaan modal kerja yang baik sehingga dapat menghindari adanya minus maupun surplus yang berlebihan. Menurut Syamsuddin (2011:209) hubungan modal kerja dengan profitabilitas menunjukkan bahwa semakin besar rasio aktiva lancar terhadap total aktiva, semakin kecil profitabilitas yang diperoleh, demikian pula dengan resiko yang dihadapi. Kebalikan dari hal ini, rasio aktiva lancar terhadap total aktiva yang semakin kecil akan meningkatkan profitabilitas dan juga risiko 
yang dihadapi. maka berdasarkan hal tersebut perlu diteliti terkait bagaimana pengelolaan modal kerja sebagai upaya meningkatkan nilai profitabilitas dan tingkat likuiditas koperasi.

\section{METODE PENELITIAN}

Penelitian ini menggunakan metode penelitian kualitatif deskriptif dengan pendekatan kuantitatif. Metode penelitian kualitatif adalah metode penelitian yang berlandasan pada filsafat post positivisme, digunakan untuk meneliti pada kondisi obyek yang alamiah, (sebagai lawannya adalah eksperimen) dimana peneliti adalah sebagi instrument kunci, teknik pengumpulan data dilakukan secara trigulasi (gabungan). Analisis data dilakukan menggunakan analisis efektivitas pengelolaan modal kerja dengan menggunakan analisis rasio, yaitu:

\section{Rasio profitabilitas}

Syamsuddin (2011:209) hubungan modal kerja dengan profitabilitas "Semakin besar rasio aktiva lancar terhadap total aktiva, semakin kecil profitabilitas yang diperoleh, demikian pula dengan resiko yang dihadapi. Kebalikan dari hal ini, rasio aktiva lancar terhadap total aktiva yang semakin kecil akan meningkatkan profitabilitas dan juga risiko yang dihadapi.

Rasio profitabilitas merupakan merupakan rasio yang menggambarkan kemampuan perusahaan dalam menghasilkan laba melalui semua kemampuan dan sumber daya yang dimilikinya, yaitu yang berasal dari kegiatan penjualan, penggunaan aset, maupun penggunaan modal. Rasio yang digunakan dalam penelitian ini adalah sebagai berikut:

a) Net Profit Margin
Menurut Syamsuddin (2011: 63), margin laba bersih merupakan ukuran keuntungan dengan cara membandingkan antara laba setelah bunga dan pajak dibandingkan dengan penjualan. Rasio ini menunjukkan pendapatan bersih perusahaan atas penjualan.

$$
\mathrm{NPM}=\frac{\text { Earning After Tax }}{\text { Sales }} 100 \%
$$

b) Return On Insvestmen (ROI)

Menurut Syamsuddin (2011: 63) Return On Investment (ROI) merupakan pengukuran kemampuan perusahaan secara keseluruhan di dalam menghasilkan keuntungan dengan jumlah keseluruhan aktiva yang tersedia di dalam perusahaan. Rasio ini membandingkan laba bersih setelah pajak dengan total aset

$$
\text { ROI }=\frac{\text { Earning After Tax }}{\text { Total Asset }} \times 100 \%
$$

c) Return On Equity (ROE)

Menurut Sartono (2012:113), suatu pengukuran dari penghasilan (income) yang tersedia bagi para pemilik perusahaan (baik pemegang saham biasa maupun pemegang saham (preferen) atas modal yang mereka investasikan didalam perusahaan. Rasio ini membandingkan laba bersih setelah pajak dengan modal sendiri.

$\mathrm{ROE}=\frac{\text { Earning After Tax }}{\text { Total Equity }} \times 100 \%$

\section{Rasio likuiditas}

Kasmir (2013:217) menyatakan bahwa dalam manajemen modal kerja kebutuhan dana juga merupakan bagian penting, baik dalam hal penyediaan dana maupun penggunaan dana yang berkaitan dengan aktivitas usaha, hal ini terdapat hubungan yang erat antara likuiditas dengan modal kerja. Rasio likuditas merupakan suatu indikator untuk menunjukan kemampuan perusahaan menggunakan aktiva lancarnya untuk membayar hutang lancar jangka pendek. 
Rasio likuiditas yang digunakan dalam penelitian ini adalah sebagi berikut:

\section{a) Net Working Capital}

Menurut Syamsuddin (2011:43), Net working capital merupakan selisih antara current asset (aktiva lancar) dengan current liabilities (utang lancar) untuk mengetahui berapa kelebihan aktiva lancar diatas utang lancar.

NWC $=$ Aktiva Lancar - Hutang Lancar

b) Current Ratio

Menurut Syamsuddin (2011:43), Current ratio merupakan rasio untuk mengukur kemampuan perusahaan dalammemenuhi kewajiban jangka pendeknya yang segera jatuh tempo dengan menggunakan aset lancar yang tersedia.

$$
C R=\frac{\text { Aktiva lancar }}{\text { Utang lancar }} \times 100 \%
$$

c) Quick Ratio

Menurut Syamsuddin (2011:45), Quick Ratio merupakan rasio yang menunjukkan kemampuan perusahaan dalam memenuhi kewajiban jangka pendeknya yang segerajatuh tempo dengan menggunakan asset sangat lancar.

$$
Q R=\frac{\text { Aktiva lancar-persediaan }}{\text { Utang lancar }} \times 100 \%
$$

\section{d) Cash Ratio}

Menurut Riyanto (2010:332), kemampuan perusahaan dalam membayar kewajiban jangka pendek dengan kas yang tersedia atau rasio yang digunakan untuk mengukur kemampuan perusahaan membayar kwajiban jangka pendeknya dengan modal yang tertanam dalam kas.

$$
\text { Cash Ratio }=\frac{\text { kas }+ \text { efek }}{\text { Utang lancar }} \times 100 \%
$$

\section{Rasio aktivitas}

Menurut Jumingan (2011:133) dalam menghitung Net Working Capital Turnover (NWCTO), dengan menghitung perbandingan penjualan dengan selisih dari aktiva lancar dan hutang lancar.

$$
\text { WCTO }=\frac{\text { Penjualan }}{\text { Aktiva Lancar }- \text { Hutang Lancar }}
$$

\section{HASIL DAN PEMBAHASAN}

Koperasi Pegawai Republik Indonesia, Universitas Malang mempunyai sejarah berdirinya sampai berkembang pada saat sekarang. Berdasarkan hasil dokumentasi dan observasi penelitian pada tangal 05 Desember 2019 yaitu pengumpulan data melalui catatan lapangan dan catatan-catatan koperasi ditemukan sejarah singkat KPPRI UB Malang. Koperasi Pegawai Republik Indonesia Universitas Brawijaya (KPRI-UB) merupakan koperasi pegawai republik Indonesia yang beranggotakan pegawai PNS atau Pegawai Non PNS dan para pegawai/karyawan lainnya, yang berdiri pada Tanggal 12 Mei 1969 dan secara resmi berdiri sebagai badan hukum No.148/11/BH/17-69 pada tanggal 12 Mei 1969 dan Akta Perubahan No. 148A/BH/17-69 pada tanggal 12 Mei 1996. Dengan alamat lengkap di J1. MT. Haryono 169 Malang. Koperasi ini Sebelumnya bernama KPRI-UB, koperasi ini bernama Koperasi Pegawai Negeri Universitas Brawijaya (KPN-UB) . Kemudian diganti dengan Koperasi Pegawai Republik Indonesia Universitas Brawijaya (KPRIUB). Memiliki Azas: Pancasila dan Undang-Undang Dasar 1945. Dan memiliki Fungsi dan Peran: Membangun dan mengembangkan potensi dan kemampuan ekonomi anggota. Serata memiliki NilaiNilai yaitu: menolong diri sendiri, demokrasi, persamaan, keadilan, solidaritas, dan keterbukaan. 


\section{Pengelolaan Modal Kerja Koperasi}

Pengelolaan modal kerja koperasi merupakan pemakaian modal kerja yang digunakan untuk menjalankan aktivitas oprasional koperasi. modal kerja KPRI-UB, dikelola dalam dua bentuk kegiatan yaitu:

a) Unit Usaha Koperasi

Koperasi Pegawai Republik Indonesia (KPRI) Universitas Brawijaya Malang memiliki tiga unit usaha yaitu Unit Usaha Simpan Pinjam, Unit Usaha Perdagangan Umum dan Unit Usaha Lain. Tiga unit usaha ini menjalakan kinerja operasional dengan menggunakan modal kerja yang dimiliki oleh koperasi. pengelolaan modal kerja tentunya diatur dalam ketentuan-ketentuan yang diketahui oleh anggota, pengurus dan pengawas koperasi.

b) Rencana Kerja Koperasi

Rencana kerja merupakan salah satu kebijakan strategis yang disusun oleh pengurus kemudian diputuskan oleh rapat anggota, sebagimana diamanatkan anggota dalam anggaran dasar dan anggaran rumah tangga KPRI Universitas Brawijaya pada pasal 13 yang diharus disahkan oleh rapat anggota. Rencana kerja ini merupakan pengembangan kinerja koperasi yang bertujuan untuk kesejahteraan anggota, hal ini terkait dengan posisi anggota sebagai pemilki dan pengguna sehingga anggota memiliki peran sentral dalam pengembangan usaha dan organisasi koperasi dan rencana kerja ini di kelola dengan menggunakan modal kerja yang dimiliki koperasi.

\section{Sumber Modal Kerja}

Sumber modal kerja dibagi menjadi anggota koperasi dan ekuitas koperasi yaitu: a) Anggota Koperasi

Modal koperasi akan terus meningkat apabila anggota koperasi bertambah setiap tahunnya, begitu juga sebaliknya apabila anggota menurun maka modal kerja kan menurun juga. Koperasi Pegawai Republik Indonesia Universitas Brawijaya Malang memiliki anggota yang berasal dari pegawai-pegawai yang ada di Universitas Brawijaya itu sendiri baik Pengawai Negeri Sipil (PNS) maupun non Pengawai Negeri Sipil (PNS). KPRI Universitas Brawijaya sangat terbuka terhadap pegawai yang ingin menjadi anggota koperasi dengan sukarela. Untuk menjadi anggota koperasi, anggota harus mengisi formulir pendaftaran dan persyaratan-persyaratan lainnya. Sebagaimana hasil wawancara yang dilakukan dengan salah satu staff bagian keuangan Koperasi, yang mengatakan:

"Pengelolan modal kerja didasari oleh sumber modal dan modal tersebut berasal dari Pihak ketiga yaitu Anggota Koperasi. Anggota Koperasi merupakan pemilik dan sekaligus pengguna jasa Koperasi Keanggotaan Koperasi dicatat dalam buku daftar Anggota. Keanggotaan Koperasi bersifat terbuka bagi semua yang bisa dan mampu menggunakan jasa Koperasi dan bersedia menerima tanggung jawab keanggotaan”.

b) Ekuitas Koperasi

Berdasarkan hasil wawancara dengan manajer utama (Ibu Suparmiati, S.Sos) dan dokumentasi catatan koperasi menyatakan bahwa

"Hal kedua yang sangat penting dalam pengelolaan modal kerja adalah modal sendiri atau ekuitas koperasi. Ekuitas koperasi 
merupakan kekayaan bersih koperasi atau selisih antara total kekayaan koperasi dengan seтиa hutangnya. Ekuitas KPRI terdiri dari simpanan pokok, simpanan wajib, modal hibah, cadangan koperasi, modal lain-lain dan SHU periode berjalan"

\section{Efektivitas Pengelolaan Modal Kerja Koperasi dalam Meningkatkan Profitabilitas dan Menjaga Likuiditas}

Untuk menilai efektivitas pengelolaan modal kerja koperasi dalam meningkatkan profitabilitas dan menjaga likuiditas, rasio yang efektif digunakan adalah rasio profitabilitas, rasio likuiditas dan rasio aktivitas. Berikut ini adalah perhitungan penilian efektivitas pengelolaan modal kerja koperasi Pegawai Republik Indonesia (KPRI) Universitas Brawijaya Malang dalam meningkatkan profitabilitas dan menjaga likuiditas koperasinya. erdasarkan teori pada landasan teori yang menyatakan bahwa profitabilitas merupakan kemampuan perusahaan memperoleh laba dalam hubungannya dengan penjualan, total aktiva, maupun modal sendiri." Jadi, profitabilitas digunakan untuk mengukur efektivitas kinerja manajemen berdasarkan hasil pengembalian yang dihasilkan dari volume penjualan, total aktiva dan modal sendiri selama periode tertentu. Dengan memiliki tingkat profitabilitas yang baik maka akan dapat memperkecil risiko bahwa perusahaan dapat membayar kewajibankewajibannya. Sedangkan Menurut Harahap dalam jurnal (Rektasiwi, 2016) mengatakan bahwa, profitabilitas adalah jumlah yang berasal dari pengurangan harga pokok produksi, biaya lain dan kerugian dari penghasilan atau penghasilan koperasi. Perhitungan Net Profit Margin Koperasi pada tahun 2016, 2017 dan 2018 disajikan pada tabel 1 berikut.

Tabel 1. Net Profit Margin (NPM) Koperasi pada tahun 2016, 2017 dan 2018

\begin{tabular}{ccccc}
\hline Tahun & $\begin{array}{c}\text { EAT } \\
(\text { RP) }\end{array}$ & $\begin{array}{c}\text { Penjualan } \\
(\text { RP) }\end{array}$ & NPM & $\begin{array}{c}\text { Kenaikan (+) / } \\
\text { Penurunan (-) }\end{array}$ \\
\hline 2016 & 1.499 .519 .594 & 80.747 .196 .686 & $9,48 \%$ & 0 \\
2017 & 1.707 .268 .474 & 91.062 .566 .282 & $9,67 \%$ & $0,19 \%(+)$ \\
2018 & 2.124 .033 .470 & 105.745 .879 .180 & $11,13 \%$ & $1.46 \%(+)$ \\
\hline
\end{tabular}

Berdasarkan tabel 1 diatas dapat disimpulkan bahwa Koperasi Pegawai Republik Indonesia Universitas Brawijaya Malang dalam meningkatkan profitabilitasnya sudah efesien walaupun pernah mengalami fluktuasi akan tetapi meningkat kembali dengan baik. Meningkatnya profitabilitas koperasi dapat dilihat dari Net Profit Margin (NPM) yang dalam tiga tahun terakhir mengalami peningkat yaitu pada tahun 2016 sebesar 9,48\% dan meningkat pada tahun 2017 sebesar 9,67\% dan membali meningkat pada tahun 2018 sebesar 11,13\%. Perhitungan Return On Insvestmen (ROI) Koperasi pada tahun 2016, 2017 dan 2018 disajikan pada tabel 2 berikut. 
Tabel 2. Perhitungan Return On Insvestmen (ROI) Koperasi pada tahun 2016, 2017 dan 2018

\begin{tabular}{ccccc}
\hline Tahun & EAT & Total Aktiva & ROI & $\begin{array}{c}\text { Kenaikan } \\
(+) / \\
\text { Penurunan } \\
(-)\end{array}$ \\
\hline 2016 & 1.499 .519 .594 & 83.287 .583 .294 & $1,80 \%$ & 0 \\
2017 & 1.707 .268 .474 & 93.751 .640 .069 & $1,82 \%$ & $0,02 \%(+)$ \\
2018 & 2.124 .033 .470 & 108.625 .498 .614 & $1,95 \%$ & $0,13 \%(+)$ \\
\hline
\end{tabular}

Peningkatan profitabilitas juga dapat dilihat dari analisis Return On Investment (ROI) yaitu pada tahun 2016 diperoleh sebesar $1,80 \%$ dan meningkat pada tahun 2017 sebesar $1,82 \%$ dan meningkat

Tabel 3. Perhitungan Return Of Equity (ROE) Koperasi pada tahun 2016, 2017 dan 2018

\begin{tabular}{ccccc}
\hline Tahun & $\begin{array}{c}\text { EAT } \\
(\text { RP) }\end{array}$ & $\begin{array}{c}\text { Modal Sendiri } \\
(\text { RP) }\end{array}$ & ROE & $\begin{array}{c}\text { Kenaikan (+) / } \\
\text { Penurunan (-) }\end{array}$ \\
\hline 2016 & 1.499 .519 .594 & 21.845 .190 .593 & $6,86 \%$ & 0 \\
2017 & 1.707 .268 .474 & 25.506 .651 .688 & $6,69 \%$ & $0,17 \%(-)$ \\
2018 & 2.124 .033 .470 & 28.220 .237 .123 & $7,52 \%$ & $0,83 \%(+)$ \\
\hline
\end{tabular}

Peningkatan profitabilitas dilihat dari analisis Return On Equity (ROE) mengalami fluktuasi pada tahun 2017 dengan rincian yaitu pada tahun 2016 sebesar $6,86 \%$ dan mengalami penurunan pada tahun 2017 sebesar 6,69\% namun mengalami kenaikan pada tahun 2018 sebesar 7,52\%.

Analisis terhadap likuiditas koperasi lebih efektif dengan menggunakan rasio likuiditas dan rasio aktivitas. Syamsuddin (2009:41) menyatakan bahwa likuiditas merupakan suatu indikator mengenai kemampuan perusahaan dalam membayar semua kewajiban finansial jangka pendek pada saat jatuh tempo dengan menggunakan aktiva lancar yang tersedia. kembali pada tahun 2018 sebesar 1,95\%. Perhitungan Return Of Equity (ROE) Koperasi pada tahun 2016, 2017 dan 2018 disajikan pada tabel 3 berikut. 
Tabel 4. Perhitungan Net Working Capital (NWC)Koperasi pada tahun 2016, 2017 dan 2018

\begin{tabular}{ccccc}
\hline Tahun & $\begin{array}{c}\text { Aktiva Lancar } \\
(\mathbf{R P})\end{array}$ & $\begin{array}{c}\text { Hutang } \\
\text { Lancar } \\
(\mathbf{R P})\end{array}$ & $\begin{array}{c}\text { NWC } \\
(\mathbf{R P})\end{array}$ & $\begin{array}{c}\text { Kenaikan (+) / } \\
\text { Penurunan (-) }\end{array}$ \\
\hline 2016 & 80.747 .196 .686 & 59.990 .667 .719 & 20.756 .528 .967 & 0 \\
2017 & 91.062 .566 .282 & 68.130 .892 .936 & 22.931 .673 .346 & 2.175 .144 .379 \\
2018 & 105.745 .879 .180 & 80.277 .904 .860 & 25.467 .974 .320 & 2.536 .300 .974 \\
\hline
\end{tabular}

Net Working Capital (NWC) menunjukan peningkatan pada likuiditas koperasi yaitu pada tahun 2016 sebesar Rp 20.756.528.967 dan mengalami kenaikan pada tahun 2017 menjadi Rp
22.931.673.346 dan kembali mengalami keniakan padatahun 2018 menjadi $\mathrm{Rp}$ 25.467.974.320. Perhitungan Current Ratio (CR) Koperasi pada tahun 2016, 2017 dan 2018 disajikan pada tabel 5 berikut.

Tabel 5. Perhitungan Current Ratio (CR) Koperasi pada tahun 2016, 2017 dan 2018

\begin{tabular}{ccccc}
\hline Tahun & $\begin{array}{c}\text { Aktiva Lancar } \\
(\text { RP) }\end{array}$ & $\begin{array}{c}\text { Lancar } \\
(\text { RP) }\end{array}$ & CR & $\begin{array}{c}\text { Kenaikan (+) / } \\
\text { Penurunan (-) }\end{array}$ \\
\hline 2016 & 80.747 .196 .686 & 59.990 .667 .719 & $134,60 \%$ & 0 \\
2017 & 91.062 .566 .282 & 68.130 .892 .936 & $133,65 \%$ & $0,95 \%(-)$ \\
2018 & 105.745 .879 .180 & 80.277 .904 .860 & $131,72 \%$ & $1,93 \%(-)$ \\
\hline
\end{tabular}

Current Ratio (CR) mengalami penurunan setiap tahun yaitu pada tahun 2016 sebesar $134,60 \%$ dan mengalami penuruan pada tahun 2017 menjadi
$133,65 \%$ serta kembali menurun pada tahun 2018 menjadi 131,72\%. Perhitungan Quick Ratio $(Q R)$ Koperasi pada tahun 2016, 2017 dan 2018 disajikan pada tabel 6 berikut.

Tabel 6. Perhitungan Quick Ratio (QR) Koperasi pada tahun 2016, 2017 dan 2018

\begin{tabular}{cccccc}
\hline Tahun & $\begin{array}{c}\text { Aktiva Lancar } \\
\text { (RP) }\end{array}$ & $\begin{array}{c}\text { Persediaan } \\
(\text { RP) }\end{array}$ & $\begin{array}{c}\text { Hutang } \\
\text { Lancar } \\
\text { (RP) }\end{array}$ & QR & $\begin{array}{c}\text { Kenaikan (+) / } \\
\text { Penurunan (-) }\end{array}$ \\
\hline 2016 & 80.747 .196 .686 & 1.356 .247 .813 & 59.990 .667 .719 & $131,88 \%$ & 0 \\
2017 & 91.062 .566 .282 & 1.581 .478 .349 & 68.130 .892 .936 & $131,33 \%$ & $0,55(-)$ \\
2018 & 105.745 .879 .180 & 1.901 .794 .023 & 80.277 .904 .860 & $129,35 \%$ & $1,98(-)$ \\
\hline
\end{tabular}

Quik Ratio $(Q R)$ juga mengalami penurunan setiap tahun yaitu pada tahun 2016 sebesar $131,88 \%$ dan mengalami penurunan pada tahun2017 menjadi $131,33 \%$ serta mengalami penurunan kembali pada tahun 2018 menjadi 129,35\%. Perhitungan Cash Ratio Koperasi pada tahun 2016, 2017 dan 2018 disajikan pada tabel 7 berikut. 
Tabel 7. Perhitungan Cash Ratio Koperasi pada tahun 2016, 2017 dan 2018

\begin{tabular}{ccccc}
\hline Tahun & $\begin{array}{c}\text { Kas } \\
(\text { RP) }\end{array}$ & $\begin{array}{c}\text { Hutang } \\
\text { Lancar } \\
(\mathbf{R P})\end{array}$ & $\begin{array}{c}\text { Cash } \\
\text { Ratio }\end{array}$ & $\begin{array}{c}\text { Kenaikan (+) / } \\
\text { Penurunan (-) }\end{array}$ \\
\hline 2016 & 14.255 .969 .078 & 59.990 .667 .719 & $23,76 \%$ & 0 \\
2017 & 15.132 .301 .822 & 68.130 .892 .936 & $22,21 \%$ & $1,55 \%(-)$ \\
2018 & 23.593 .436 .764 & 80.277 .904 .860 & $29,39 \%$ & $7,18 \%(+)$ \\
\hline
\end{tabular}

Cash Ratio mengalami fluktuasi yaitu pada tahun 2016 sebesar $23,76 \%$ dan mengalami penurunan pada tahun 2017 menjadi $22,21 \%$ serta mengalami kenaikan pada tahun 2018 menjadi 29,39\%.
Perhitungan Perputaran Modal Kerja (Working Capital Turn Over) koperasi pada tahun 2016, 2017 dan 2018 disajikan pada tabel 8 berikut.

Tabel 8. Perhitungan Current Ratio (CR) Koperasi pada tahun 2016, 2017 dan 2018

\begin{tabular}{|c|c|c|c|c|c|}
\hline Tahun & $\begin{array}{l}\text { Penjualan } \\
\text { (RP) }\end{array}$ & $\begin{array}{c}\text { Aktiva Lancar } \\
\text { (RP) }\end{array}$ & $\begin{array}{c}\text { Hutang } \\
\text { Lancar } \\
(\mathrm{RP})\end{array}$ & WCTO & $\begin{array}{c}\text { Kenaikan (+) / } \\
\text { Penurunan (-) } \\
\text { Kali }\end{array}$ \\
\hline 2016 & 15.806.161.102 & 80.747 .196 .686 & 59.990 .667 .719 & $\begin{array}{l}0,76 \\
\text { kali } \\
0,77\end{array}$ & 0 \\
\hline 2017 & 17.646 .902 .472 & 91.062 .566 .282 & 68.130 .892 .936 & $\begin{array}{c}\text { kali } \\
0,74\end{array}$ & $0,01(+)$ \\
\hline 2018 & 19.067 .528 .410 & 105.745 .879 .180 & 80.277 .904 .860 & kali & $0,03(-)$ \\
\hline
\end{tabular}

Berdasarkan pernyataan diatas dapat disimpulkan bahwa Koperasi Republik Indonesia Universitas Brawijaya (KPRIUB) Malang dalam menjaga tingkat likuiditasnya mengalami penurunan secara perhitungan rasio likuiditas sedangkan dilihat dari daftar pembayaran kewajiban jangka pendek koperasi (gambar.) koperasi mampu memenuhi kewajibanya maka dari itu penurunan rasio likuiditas disebakan KPRI UB menggunkan Kas koperasi untuk membayar keawajiban jangka pendeknya. Dalam menilai efektivitas kinerja penggelolan modal kerja di perlukan anlisis rasio aktivitas hal ini dikarenan kita perlu tahu mengenai bagaimana kemapuan koperasi dalam menggelola aktiva lancarnya untuk menjalankan operasional koperasi. Rasio aktivitas merupakan rasio untuk ukuran penilaian kinerja perusahaan yang dimaksudkan untuk mengukur sampai seberapa besar efektivitas perusahaan dalam menggunakan sumber-sumber dananya. Berdasarkan hasil analisis rasio aktivitas yang digunakan yaitu rasio Perputaran Modal Kerja (Working Capital Turn Over) merupakan kemampuan modal bersih berputar dalam satu periode siklus kas perusahaan. Berikut ini adalah hasil analisisnya.

\section{KESIMPULAN}

Sumber pengelolaan modal kerja koperasi pegawai Republik Indonesia, Universitas Brawijaya Malang adalah bersumber dari anggota dan ekuitas sendiri 
koperasi. Sedangkan ekuitas sendiri koperasi bersumber dari simpanan pokok, simpanan wajib, modal hibah, cadangan koperasi, modal lain-lain dan SHU periode berjalan. Sumber modal koperasi tersebut digunkan untuk membiayai modal kerja koperasi dalam menjalankan operasional koperasi sehari hari. Kegiatan operasional yang dimaksud adalah unit usaha koperasi dan rencana kerja koperasi.

Efektivitas peningkatan profitabilitas dan menjaga likuiditas koperasi, diketahui berdasarkan hasil analisis yang dilakukan ditemukan bahwa tingkat profitabilitas koperasi sudah sangat baik hal ini terbukti dengan hasil analisis terhadap Net Profit Margin (NPM) yang terus meningkat dalam tiga tahun terakhir yaitu pada tahun 2016 sampai pada tahun 2018 dan Tingkat profitabilitas juga mengalami kenaikan pada hasil ROI. Sedangkan hasill rasio ROE mengalami fluktuasi. Untuk pengukuran Net Working Capital (NWC) mengalami kenaikan dalam tiga tahun terakhir sedangkan Current Ratio (CR) cenderung mangalami penurunan. Hal serupa juga terjadi pada Quick Ratio (QR) yang cenderung mengalami penurunan yaitu pada tahu tahun 2016 sampai pada tahun 2018 menjadi. Sedangkan Cash Ratio (CR) mengalami fluktuasi. Sedangkan rasio aktivitas merupakan rasio untuk mengukur kinerja koperasi dalam mengelola aktiva lancarnya. Rasio yang digunakan adalah rasio Perputaran Modal Kerja (Working Capital Trun Over). Tingkat aktivitas perputaran modal kerja dilihat dari pertumbuhan rasio aktivitas dari tahun 2016 sampai pada tahun 2018 mengalamai fluktuasi. Hal ini disebakan oleh tingkat penjualan koperasi yang kecil dari pada tingkat kewajiban lancar koperasi.

\section{DAFTAR PUSTAKA}

Agus, H., Martono. 2011. Manajemen Keuangan. Edisi Kedua. Cetakan Pertama. Penerbit EKONISIAL Yogyakarta.

Antoni,S. Topowijono, Devi, F. 2013. Efektivitas Pengelolaan Modal Kerja Koperasi Dalam Meningkatkan Profitabilitas Dan Menjaga Tingkat Likuiditas. Jurnal Administrasi Bisnis (JAB) Vol. 27 No. 1: 1-10.

Azlina, N. 2009. Pengaruh Tingkat Perputaran Modal Kerja, Struktur Modal Dan Skala Perusahaan Terhadap Profitabilitas. Pekbis Jurnal, Vol.1 No.2 : 107-114.

Fauziyyah, L.,\& Husaini, A. 2017. Analisis Sumber Dan Penggunaan Modal Kerja Dalam Upaya Meningkatkan Profitabilitas Perusahaan (Studi pada PT Express Transindo Utama Tbk Periode 2013-2016). Jurnal Administrasi Bisnis (JAB) Vol.48 No.1: 155-164.

Munawir. S. 2014. Analisa Laporan Keuangan. Liberty. Yogyakarta.

Nola, R.O. Fransisca, Y., \& Dwiatmanto. 2016. Efektivitas Pengelolaan Modal Kerja Dalam Meningkatkan Profitabilitas Dan Menjaga Tingkat Likuiditas (Studi Penelitian Pada Kud "Karya Bhakti" Jombang Tahun 2011-2015). Jurnal Administrasi Bisnis (JAB) Vol. 40 No.1:60-66.

Riyanto, B. 2010. Dasar-Dasar Pembelanjaan Perusahaan. Edisi 4. Yogyakarta: BPFE.

Sartono, A. 2010. Manejemen Keuangan Teori dan Aplikasi. Edisi 4. BPFE. Yogyakarta.

Sopini, P., Trifani, C., Y. 2017. Analisis Sumber Dan Penggunaan Modal Kerja Pada Mini Market Pelangi Jambi. Jurnal of Economics and Business Vol.1 No.1: 197-212 
Referensi : Jurnal Ilmu Manajemen dan Akuntansi Vol. 8, No.1, 2020. Hal 79-89

Syamsuddin, L. 2011. Manajemen

Keuangan Perusahaan. Jakarta: PT.

Rajagrafindo Persada.

Sugiyono. 2015. Metode Penelitian

(Kuantitatif, Kualitatif Dan R\&D).

Bandung: Alfabeta.

Undang-Undang Republik Indonesia

Nomor 17 Tahun 2012 Tentang

Perkoperasian.
Yuandi K., \& Timbul. 2013. Perputaran Modal Kerja Dalam Mengukur Tingkat Profitabilitas Pada Pt. Jasa Angkasa Semesta, Tbk. Jakarta. Jurnal EMBA 135 Vol.1 No.4 : 134140. 